\title{
Reforming Value Added Tax System in Developing World: the Case of Nepal
}

\author{
Sanjaya Acharya \\ Correspondence: Sanjaya Acharya, Oxford Policy Management, UK
}

Received: January 28, 2016

doi:10.11114/bms.v2i2.1616
Accepted: February 14, 2016 Online Published: May 18, 2016

URL: http://dx.doi.org/10.11114/bms.v2i2.1616

\begin{abstract}
Value Added Tax (VAT) has become an integral part of domestic tax reforms in many developing countries. Taking the case of Nepal, VAT associates a number of refunds to different private sector activities for promoting investment in higher growth and export potential sectors. Total refund, more specifically, export refund has a significant positive impact on the level of GDP. Furthermore, non-agricultural GDP has strong positive influence to VAT C-efficiency ratio. Likewise, higher the VAT gap, lower is the C-efficiency ratio. If C-efficiency is improved coupled with higher compliance, the capability of the government is strengthened in domestic revenue generation.
\end{abstract}

Keywords: VAT, C-efficiency ratio, VAT gap, growth, tax compliance

JEL Classification: H20; H21; H25; H24; K27; K34;

\section{Introduction}

The rapid rise of the value-added tax (VAT) was the most dramatic — and probably most important— development in taxation in the latter part of the twentieth century, and it still continues. Forty years ago, the tax was barely known outside theoretical discussions and treatises. Today, however, it is a key component of the tax system in over 160 countries, raising about one-fourth of the world's tax revenue.

Domestic indirect taxes, before the introduction of VAT, were typically limited to narrowly defined products, such as alcohol and tobacco, and to sales and turnovers. In the wake of governments' need in raising revenue in the situation of high distortions associated with turnover taxes coupled with import tariff revenues lost as a consequence of trade liberalization compelled many countries explore less distortionary alternatives. VAT was a good substitute for it. Countries were slow in adopting VAT due to relatively higher level of competency required in its implementation.

VAT differs greatly across the countries with reference to its elasticity in mobilizing the revenue for the government. Three ratios, namely, efficiency ratio, c-efficiency ratio and VAT gross collection have been used to assess the performance of the VAT in different countries. Generally low ratios indicate the erosion of the VAT base. Furthermore, on the basis of these ratios, the International Monetary Fund (IMF) has recently noted two gaps, namely, coverage gap and administrative gap in Nepal. The former refers to the extent to which some of the potential tax base has been excluded from the design of the tax and the latter refers the extent to which the tax is not effectively administered.

Some administrative risks exist in VAT implementation. The experience of many countries indicates the risk of under reporting of sales by registered firms, submission of false invoices, false export claims, failure to remit the tax collected to the government and the non-registration of firms above the threshold as the most common modes of VAT evasion. In developing countries like Nepal where major businesses are carried by small scale firms, accounting is unreliable and tax administration is weak culminating into weak VAT implementation. VAT implementation in Nepal is stemming from this background.

This study is based on the secondary data published by the Inland Revenue Department (IRD), Ministry of Finance (MOF) and other resources. Moreover, the outcomes of the quality circle discussions with experts on taxation both in IRD and members of the high level tax review committee of Nepal were crucial to this study. The study conducts trend analysis of the data and then diagnoses how VAT return system is instrumental to the growth performance of the economy. Moreover, it has estimated Nepalese VAT efficiency ratio and its correlates as well. Furthermore, the study establishes relationship between VAT gap and VAT C-efficiency ratio. 


\subsection{Research Questions and Propositions}

This study makes a comprehensive review of VAT implementation in Nepal for the last 17 years to which the systematic data are available. Series of VAT reforms are underway in this connection. Although grown in terms of volume, the efficiency in VAT collection has not yet been estimated and analyzed. In addition to fulfilling this gap, this research also assesses the growth impact of the potential efficiency gain in Nepalese VAT system. Furthermore, this research also explores the correlates of VAT efficiency ratio in Nepalese economy. To sum-up, the research question of this paper is how VAT efficiency is changing over time and how different parameters are making impact on it. In order to answer this question, the research will test the following propositions:

- The C-efficiency ratio of VAT in Nepal is improving over time.

- The C-efficiency ratio has direct positive impact on GDP, more specifically on non-agricultural GDP.

- C-efficiency ratio itself is dependent on the size of VAT gap, budget deficit, size of urban population in the country, and the GDP growth rate.

In testing these propositions and answering the research question, the rest of this paper is organized as follows: Section 2 reviews the relevant literature on VAT reform, more specifically in the case of developing world. Models, results and discussions are the subject matters of Section 3. It also presents the trend analysis of VAT implementation and GDP growth in Nepal. Moreover, this section also presents the analysis of data, more specifically, the VAT return system, gap analysis, refund system and its impact on growth. Furthermore, establishment of the relationship of C-efficiency ratio with VAT gap, GDP growth, urbanization, trade openness, and budget deficit are also integral parts of this section. Section 4 concludes.

\section{Literature Review}

Global experience does not reveal particular variable associated with the specification of the VAT threshold. To take an example, Gambia Revenue Authority has considered several factors in determining the threshold; however, it also lacks the quantification of the threshold with relative shares distributed among the determining factors. Variables considered in determining the threshold were found to be recurrent and project related turnover on goods and services in Gambia, and export of goods and services whose consumption is outside Gambia. However, variables not considered in determining the threshold were sale of capital assets, sale of whole or part of a business, exempt supplies, and sale from a business operating outside Gambia (VAT Guide 2014, p. 14, Gambia Revenue Authority). In case of India, the government has established a system of annual review of VAT threshold. South Africa which implemented VAT in 1991 has been developing it as a very successful tax system along with fairly high registration threshold and limited exemptions to basic food items and paraffin.

Several developing economies with similar level of economic development have adopted single VAT rate. Of the total 21 African countries that implemented VAT between 1990 and 1999, 14 have adopted single rate. Likewise, of the nine countries that implemented VAT after 2000, eight have applied the single rate. The rate, however, is determined based on the country specific conditions and the revenue requirements. European Union has a minimum of 15 percent, with 10 percent in Australia, 15 percent in New Zealand and 14 percent in South Africa (Owens \& Battiau, 2011).

OECD economists have long supported the view that, all things being equal, a broad based and single-rate VAT is the preferred tax approach for growth and equity. In its 2010 Green Paper on "The Future of VAT" the European Commission suggests that a broad-based VAT system with a single rate would be quite close to the ideal of a pure consumption tax that minimizes compliance costs (Ibid). Moreover, many countries justify reduced rates as a way of not penalizing the poorest households for buying daily essentials since these households have high marginal propensity to consume - especially food and clothing. A single VAT rate with some compensatory measures targeted to the poorer households would be an ideal strategy in protecting the interest of the poor.

Significant differences exist among experts regarding the basic features that should be taken into account for the successful implementation and effective administration of a VAT; however, in the context of capacity building and strengthening, a lot of common grounds are apparent among many developing countries. Most importantly, multiple rate structures and non-harmonized compliance and enforcement rules create unnecessary complexity, uncertainty, and inefficiencies. Wider definition of taxable person/enterprises (including government bodies), high registration threshold, single rates, minimal exemptions, and minimal zero-rated supplies are more preferred compared to the opposite cases, Lejeune (2011).

In case of Bangladesh, one of the most important weaknesses of pre-VAT excise system was multiple rates (Rouf, 2015). Multiple rates of taxation made the tax management complex and discretionary powers of the officers were frequently misused. Still Bangladesh VAT has nine reduced rates along with one standard 15 percent rate and one zero rate. In this way, there are a total of 11 rates and this has invited a series of considerations for improvement. 
Nepal has been adopting single VAT rate since its inception in 1997. After eight years of administration of standard VAT rate of 10 percent, the rate was raised to 13 percent in 16 July 2005. Global experiences, however, are varying based on existing administrative capacity of the government, tax education among businessmen regarding proper book keeping, the culture of conducting business, and compliance cost of the tax payers. However, for the last several years, business community is lobbying for multiple VAT rate in Nepal in view of tax favor to different business activities. Introducing several VAT rates will definitely complicate the Inland Revenue administration and the compliance. However, if the existing list of exemption goods are transferred to zero rate, goods with different refund rates are applied with half of the standard rate of VAT, and the rest are applied with standard 13 percent VAT rate, this change does not necessarily increase the compliance cost rather it improves efficiency in VAT administration.

Despite the single rate policy followed by the Nepalese government, multiple rates exist in Nepalese VAT system in one way or another. A long list of exemption goods, and varying rates of refund to different goods such as vegetable ghee, sugar, wheat flour, and mobile imports in the range of 40 to 70 percent, and 13 percent standard VAT rate to other goods/services have made the Nepalese VAT at least three-tiered in terms of the rate. Should Nepalese government try to address the demand of the business sector and improve the compliance within the given tax administration cost, 13\%, $6 \%$, and $0 \%$ might be the three rates to administer that is not essentially different from the current rate structure.

The impact of VAT exemption and refund on economic growth requires the diagnosis of the income and substitution effects of the VAT imposition along with changes in its rate structure. The theory on income and substitution effects stem to consumption and investment effects. Change in consumption affects the level of domestic production; whereas change in the level of capital stock due to high domestic and foreign demand directly affects the growth performance of the sectors affected by exemption and refund system.

Studies are absent in analyzing the growth implications of VAT structure in Nepal; however, Ethiopian experience (Jalata, 2014) reveals that overall change in the consumption and investment in an economy following the changes in VAT structure is not sufficient to explain the growth impact of VAT but improvement in VAT administration and compliance are even more important to deliver the positive changes.

Following section also continues the review of literature on VAT refund system and VAT gap analysis.

\section{Model, Results, and Discussion}

In Nepal VAT was implemented in 1997 by replacing the sales tax, entertainment tax, hotel tax, and contract tax. When introduced, Nepal's VAT comprised sufficiently high registration threshold, relatively few exemptions, a rate structure with a single positive rate, and zero-rating limited to exports with an adequate refund system. There have been significant changes in some of these areas since the adoption of VAT. The registration threshold was considered as sufficiently high to ensure the number of VAT registered enterprises in line with the administrative capacity of the VAT department.

The implementation of VAT in Nepal has passed more than a decade and half so far. During this time the Nepalese Economy has undergone significant changes in volume, structure and contribution of public sector revenue. Similar to other developing countries, it has become the mainstay of government revenue collection contributing to nearly half of the total indirect tax collection in Nepal. Moreover, the introduction of self-assessment system, functional based organization, and risk based audit selection system has initiated significant reform in the tax administration.

VAT revenue is constantly growing from its inception in 1997 and has now appeared as the single biggest source of tax revenue of the government. Tax revenue progression has been rather strong since 2010/11. Current efforts of improving tax collection are expected to raise the tax revenue from 16.3 percent (Fiscal Year 2013/14) to about 18 percent of GDP in FY 2017/18 along with few ups and downs. Constant improvement in the revenue performance of the government has caused tax revenue to GDP ratio reach over 12 percent now as compared to less than nine percent before VAT implementation.

\subsection{VAT Revenue Growth}

The number of VAT registered enterprises has significantly increased - from 2,000 registered traders when the VAT was introduced in 1997 to more than 150,000 now with average annual growth of 31 percent during the last 17 years; however, the share of the domestic VAT remains less than 35 percent in total VAT collection. Share of import VAT is consistently growing and has now peaked to about two-thirds of total VAT collections which signify the need of investigation and reforms in domestic VAT collection regarding its dismal performance. 


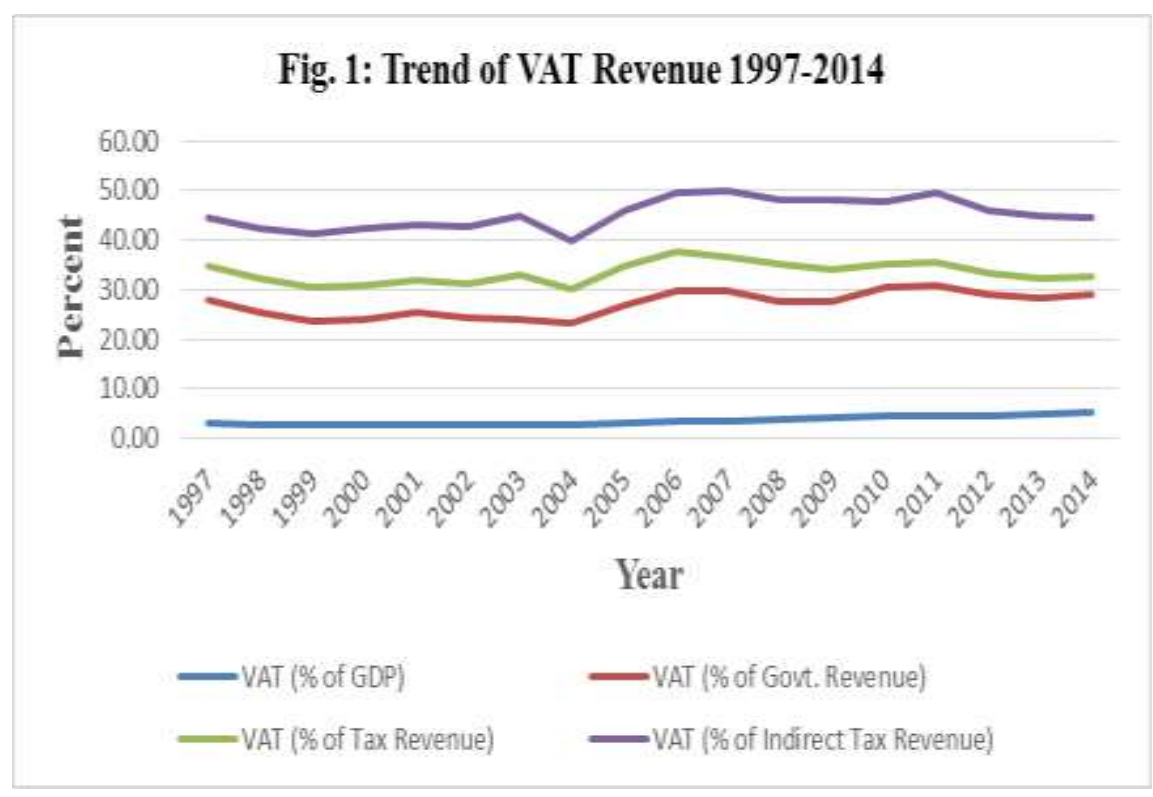

Figure 1. Trend of VAT Revenue 1997-2014

Data source: Economic Survey, various issues, Ministry of Finance.

A short glance on Figure 1 shows marginal rise in the VAT revenue as a percentage of GDP, percentage of overall revenue, tax revenue, as well as that of indirect tax revenue from its inception in 1997 till 2003. The growth rate is a bit higher from 2004 to 2011; however, it moderated after 2011. VAT collections increased from 2.7 percent of GDP initially to 3.3 percent in 2005/06 (after an increase of the standard rate from 10 to 13 percent) and to 5.3 percent in 2013/14 (Table 1). During this period, the share of VAT in total tax revenue increased from 32 percent in 1997/98 to over 36 percent in 2006/07, but subsequently lessened to about 33 percent. Likewise, VAT contribution to total indirect tax revenue increased from about 42 percent to almost 50 percent in 2006/07 but gradually declined thereafter to reach about 44 percent in 2013/14.

Table 1. VAT with reference to major macro-aggregates in Nepal, 1997-2014

\begin{tabular}{llllll}
\hline & $1997 / 98$ & $2001 / 02$ & $2006 / 07$ & $2010 / 11$ & $2013 / 14$ \\
\hline GDP (Billions of NPR) & 300.8 & 459.4 & 727.8 & $1,346.8$ & $1,931.0$ \\
Consumption (Billions of NPR) & 259.4 & 415.8 & 656.4 & $1,257.2$ & $1,759.1$ \\
VAT collections (Billions of NPR) & 8.3 & 12.3 & 26.1 & 61.7 & 103.0 \\
VAT standard rate & 10 & 10 & 13 & 13 & 13 \\
Ratio of VAT to GDP & 2.78 & 2.67 & 3.58 & 4.58 & 5.33 \\
Ratio of VAT to Consumption & 3.22 & 2.95 & 3.97 & 4.91 & 5.85 \\
Share of VAT in total tax revenue & 32.19 & 31.20 & 36.68 & 33.49 & 32.64 \\
\hline
\end{tabular}

Source: IRD and the Ministry of Finance.

Table 1 shows the growth of VAT and its base, i.e. the domestic consumption. However, a deeper examination is indeed important whether VAT revenue growth is consistent with its base growth; Section 3.2 raises this issue and analyzes with reference to the VAT Gap.

\subsection{VAT and Nepalese Tax Revenue}

VAT shares the highest tax revenue compared to other tax types in Nepal. Figure 2 shows constant dominance of VAT among four major taxes in Nepal (in terms of revenue collection): VAT, import duties, excise duties, and income tax. Relative contribution of import duties and income tax seem to equalize over the years. 


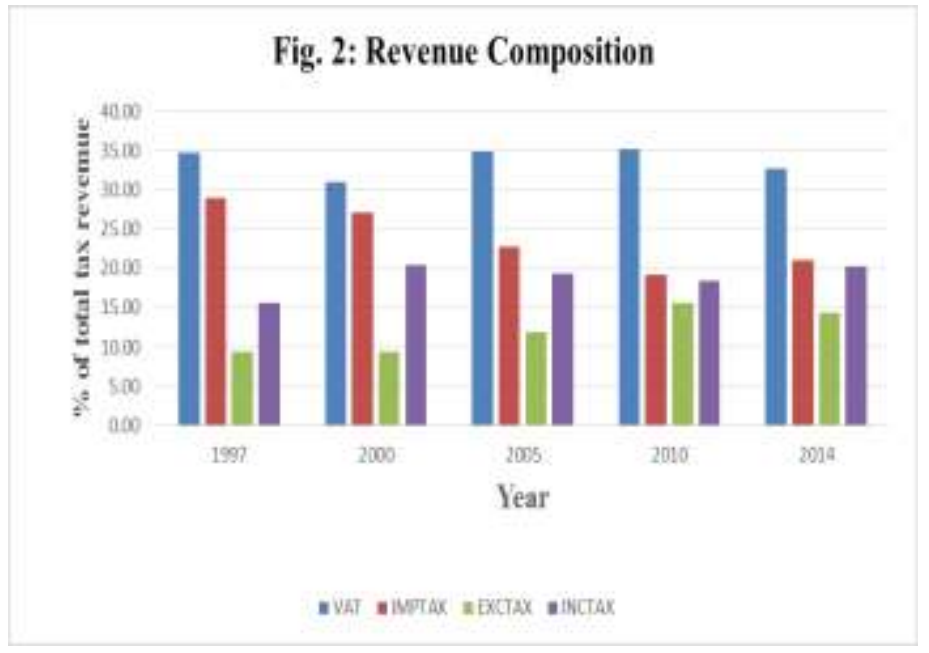

Figure 2. Revenue Composition

Currently, VAT shares approximately one-third of Nepal government's total tax revenue. Despite this role, overall tax compliance - especially VAT compliance - remains at a low level partly because of the large informal sector activities. Moreover, reforms of the excise taxes that should have accompanied the adoption of VAT in order to modernize the entire indirect tax system are rather slow. With a majority of low-yield excises for more than 50 items, and a fragmented excise tax administration, substantial improvements still require in this tax in co-ordination with VAT.

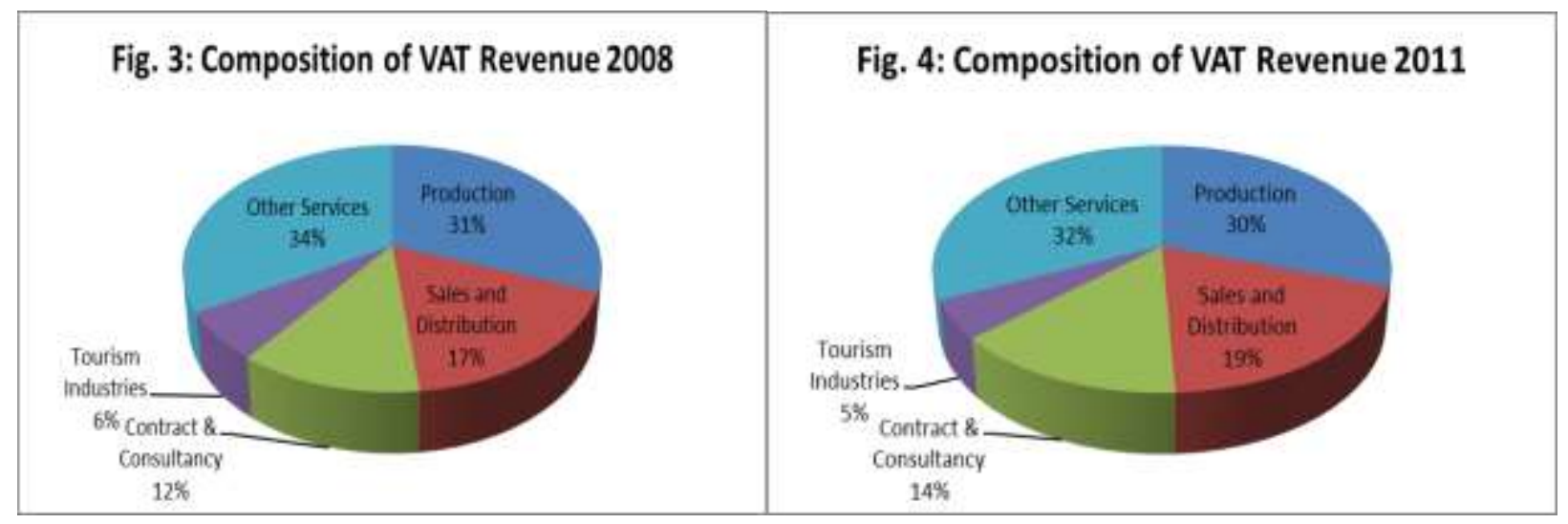

Figure 3. Composition of VAT Revenue 2008

Figure 4. Composition of VAT Revenue 2011

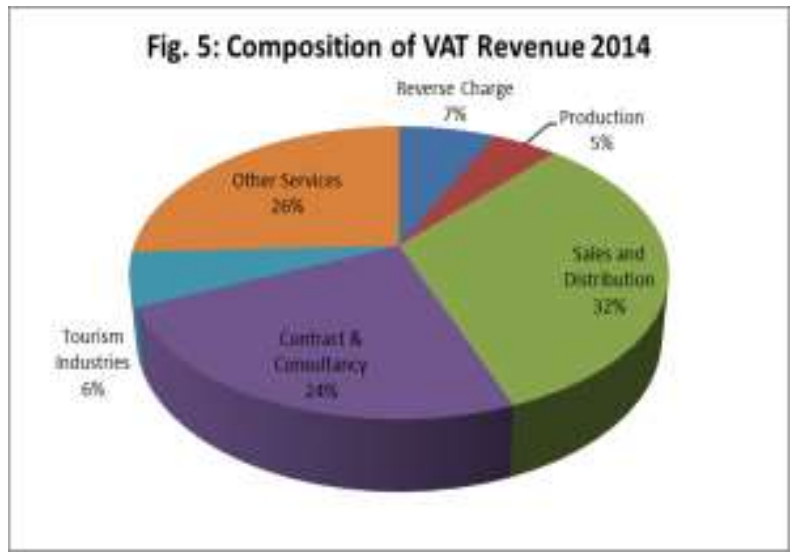

Figure 5. Composition of VAT Revenue 2014

Data source: IT Division, Inland Revenue Department, Kathmandu.

Note: Years 2008, 2011, and 2014 refer to FY 2007/08, 2010/11, and 2013/14, respectively.

During the last seven years, structural changes in the composition of VAT revenue are apparent. VAT revenue from production activities has declined from 31 percent of overall VAT revenue (2008) to just five percent (2014). On the 
other side, the contribution from sales and distribution activities has gradually increased from 17 to 32 percent. Similar is the case of contribution from contract and consultancy services from 17 to 24 percent (Figure 3, 4, and 5). This is worrisome that production activities are losing their strength in revenue generation and sales/distribution/contract/consultancy activities are swelling signifying the lack of improvement in the productive strength of the economy.

\subsection{Analysis of VAT Return System}

The trend of return submission does not show the encouraging picture as a percent of credit return and zero return far exceed debit return (Table 2) indicating that number of taxpayers having profitable transaction is lower in comparison to the taxpayers for whom government is liable to refund tax plus number of taxpayers having zero transaction ${ }^{1}$. Provision of zero rates is also one of the causes for the increment of credit return; however, increasing number of low/under invoicing, no- invoicing and abbreviated invoicing are more apparent for higher credit return (Gautam, 2014).

Table 2. Status of VAT returns submission

\begin{tabular}{llllllll}
\hline Fiscal Year & Credit return & Percent & Debit return & Percent & Zero return & Percent & Total return \\
\hline $2005 / 06$ & 130,106 & 48.43 & 55,579 & 20.69 & 82,978 & 30.89 & 268,663 \\
$2006 / 07$ & 139,804 & 49.16 & 56,465 & 19.85 & 88,127 & 30.99 & 284,396 \\
$2007 / 08$ & 153,502 & 49.15 & 61,305 & 19.63 & 97,515 & 31.22 & 312,322 \\
$2008 / 09$ & 170,949 & 48.96 & 65,149 & 18.66 & 113,043 & 32.38 & 349,141 \\
$2009 / 10$ & 196,857 & 36.3 & 72,466 & 27.99 & 133,043 & 35.52 & 403,165 \\
$2010 / 11$ & NA & 27.44 & NA & 35.55 & 133,842 & 36.67 & NA \\
$2011 / 12$ & 289,439 & 36.85 & 102,257 & 27.7 & 195,184 & 36.05 & 586,880 \\
$2012 / 13$ & NA & 40.1 & NA & 25.43 & NA & 34.45 & NA \\
$2013 / 14$ & 393,429 & 45.49 & 122,246 & 27.14 & 210,934 & 27.37 & 726,609 \\
\hline
\end{tabular}

Source: Annual Report 2013/14, Inland Revenue Department, Kathmandu. Values are in Rupees.

Besides, zero return also indicates the increasing number of registered small taxpayers (below the threshold). This is particularly attractive to them due to the requirement of submitting the VAT registration certificate at the time of bidding government contract (Khadka, 2004).

Efforts of extending the VAT base along with over-relaxed and unverified registration have resulted in growing number of non-filers (Acharya \& Dhakal, 2011). Number of non-filers is growing rapidly in successive years. Almost one quarter of all registered businesses simply do not file periodic VAT returns. Likewise, more than 50 percent of all businesses file negative returns, and around one third of all VAT returns indicate no transactions, which means that only 15 percent of the returns actually produce revenues for the state (Sharma \& Sarker, 2014). Moreover, a large negative return coupled with limited export performance indicates abusive practices or fraud in the part of the business.

\subsection{VAT Gap Analysis}

As mentioned earlier, VAT Gap -- the difference between projected revenue and actual revenue during a particular time ${ }^{2}$ -- is a problem in the presence of large informal economy. The key variables that explain wider VAT gap in the developing world are the structure of the economy, lack of effective enforcement of the tax law and weak tax morality. Although VAT gap is often associated with tax evasion and avoidance, a broader measure of tax gap is simply a non-compliance. ${ }^{3}$

As VAT gap is the difference between VAT potential and VAT collection, first we assess VAT base and subsequently estimate the VAT potential. VAT base by definition is the value derived from total transaction minus total necessary deduction plus total addition. Our estimation of VAT gap in this study follows widely used Top-down Approach where we start with the total consumption and investment expenditure data available from Nepal Economic Surveys, various issues, published by the Ministry of Finance. We follow the approach adopted by Acharya and Dhakal (2011) in deriving total deduction and total addition to apply on total consumption and investment expenditures in order to reach

${ }^{1}$ Debit returns (positive tax liability- tax paid during purchase of goods and services is lower than tax received from the sales of goods and services) credit return (negative tax liability - tax paid during purchase of goods and services is higher than tax received from the sales of goods and services) Zero Return ( Zero- tax liability- zero transaction.)

2 P Shome, "The control of tax evasion and the role of tax administration" in Tax Systems and Tax Reforms in South and East Asia (Routledge: New York 2006) edited by L Bernardi et al., p. 40.

3 D Rifkin, “A Primer on the Tax Gap and Methodologies for Reducing It,” 27 Qunnipiac Law Review 375 [Rifkin], p. 377; Robina Ather Amed and Mark Rider, "Pakistan's Tax Gap: Estimates by Tax Calculation and Methodology", Georgia State University Andrew Young School of Policy Studies, International Studies Program Working Paper 08-11 [“Ahmed and Rider"], p. 3. 
total effective VAT base. For details regarding total deductions and additions in estimating VAT Gap, please refer Annex A2.

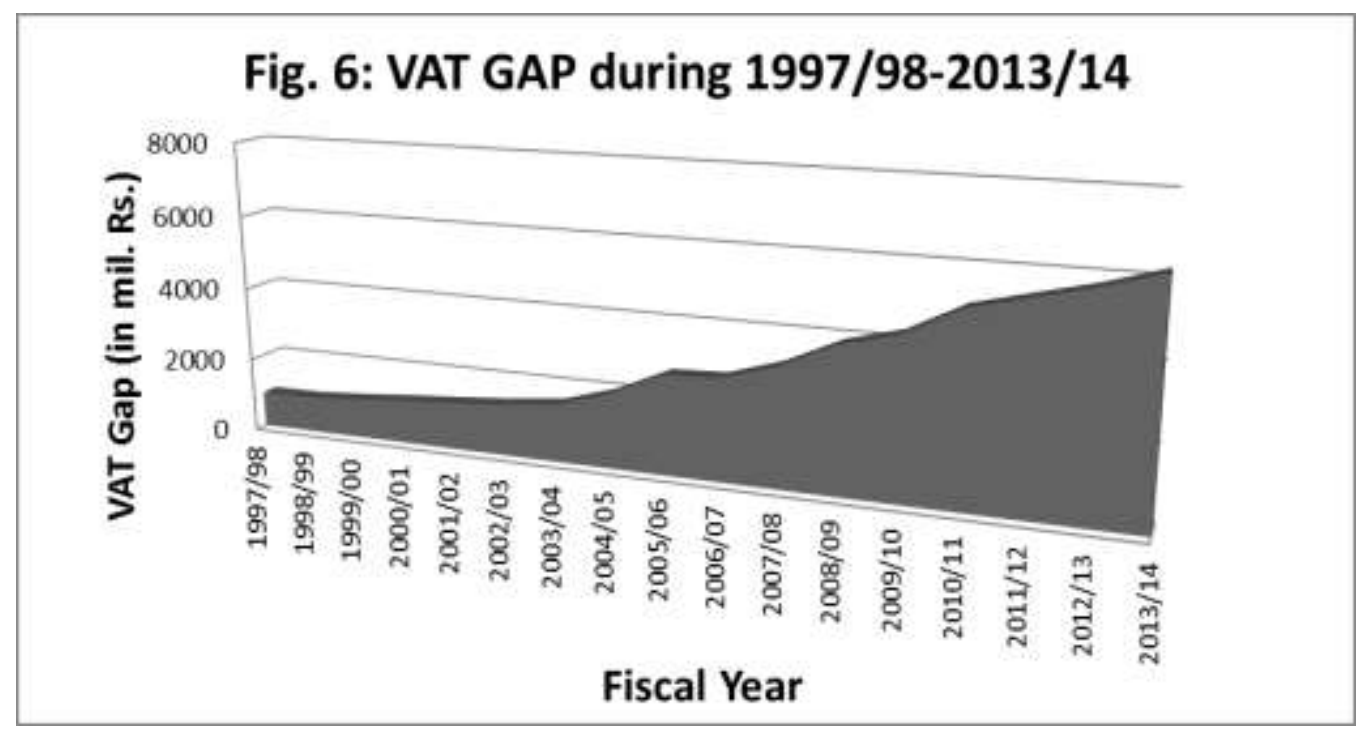

Figure 6. VAT GAP during 1997/98-2013/14

VAT gap is the result of unaccounted systematic default of VAT design ${ }^{4}$. Theoretically, it is simply a gap between expected and actual VAT collection, however, in practice it pictures the entire compliance level of VAT implementation. VAT gap rises due to evasion and fraudulent behavior of taxpayers. Some taxpayers intentionally search ways to evade tax while some unintentionally do. Especially small taxpayers often try to avoid tax in raising their saving and extend their business. Fraudulent behavior is associated with those having black transactions i.e. low invoicing, and smuggling.

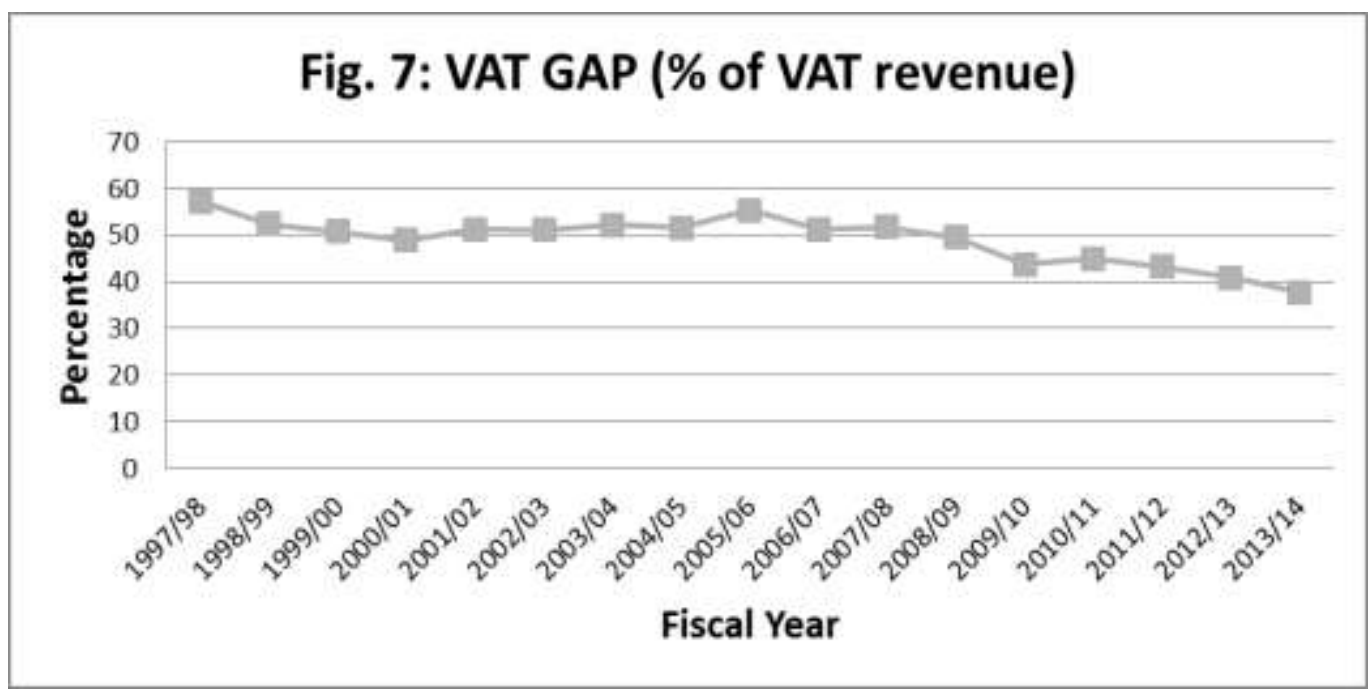

Figure 7. VAT GAP (\% of VAT revenue)

Besides, implication of VAT laws can also be taken as a reason for increasing trend of VAT gap. Complex provisions of invoicing, return filing and additional accounting requirement ${ }^{5}$, frequent amendment in VAT laws, relatively higher tax rate, similar penalty for all taxpayers irrespective of the level of business, weak grievance handling mechanism are some the flaws of VAT Act. Furthermore, high bank guaranty required even to low bid amount provisioned in the procurement act has also played a role for VAT evasion by small taxpayers. Small taxpayers are often found evading VAT to raise their saving in meeting the bank guaranty.

\footnotetext{
4 Acharya and Dhakal (2011).

5 Acharya and Dhakal (2011) p. 45.
} 
These are some of the causes of widening VAT gap in Nepal. As presented in Figure 6 and Annex Table A2, VAT gap has been swelling since its implementation in 1997. Snowballing of VAT gap is also associated with the politico-economic situation of Nepal. The trend of VAT gap was not that much high before fiscal year 2003/04 as the political and economic environment was relatively stable. After the political change in FY 2003/04, the royal government was unable to deliver effective revenue administration; the same applied particularly to VAT administration as well. VAT gap as a percentage of VAT revenue revealed upward spiral and peaked-up in FY 2005/06 as the royal government lost the credibility of the business sector. However, political change in 2006 established the democratic government and revenue administration also improved; consequently, VAT gap as a percentage of VAT revenue has been constantly declining now as compared to before 2006.

Dual gaps in policy and implementation, presence of informal economy, global competition and impact on tax incidence, and issues of exemption are the major reasons behind the wide VAT gap in the developing economies. The shadow economy undermines the stability of revenue collection and equity among taxpayers as large amounts of income from activities taking place in the informal sectors escape untaxed; however, similar activities are taxed in the formal sector (Phua, 2011). A study in 145 countries estimates that the average size of the shadow economy in developing countries is approximately 40 percent of the official $\mathrm{GDP}^{6}$. Indian experience reveals that workers in the primary sector consist of approximately 90 percent of the informal workforce (based on national survey between 1999 and 2005). ${ }^{7}$ This is almost 75 percent in Kenya ${ }^{8}$ and 30 percent in the Philippines ${ }^{9}$. Furthermore, complex tax paying procedures, high compliance cost, and endemic corruption are other reasons for wide VAT gap in many countries. ${ }^{10}$ Long list of tax exempted goods and services also cause the increasing trend of VAT gap. Removing the exemption could upsurge the revenue. Simplifying VAT law and removing the exemption for intermediate consumption would reduce compliance and administration costs and help close the compliance gap (Eric Hutton, 2014).

\subsection{Growth Impact of the Refund System: Models and Results}

Some items are completely exempted from VAT - called as zero-rated. Therefore, registered firms/persons making zero-rated sales may take full credit for the VAT paid on the taxable inputs to his/her business. The provision for zero rated goods and services transaction should follow the procedure right from the VAT registration. Zero rated products are entitled to receive input tax refund. They include export of goods and services and consumption by diplomatic communities. Furthermore, the supplies to export processing zone and export trading house with the purpose of export is also considered as export related activities; however, this provision creates possibility of VAT evasion as the products from the export processing zone do not always necessarily follow the export route. The other provisions on zero rate include the scooter for the use of disabled person and solar battery and supplies to hydropower projects. Acharya \& Dhakal (2011) recommend the need of exploring other incentives rather than zero rate which is prone to develop the leakages due to the lack of effective monitoring.

In order to observe the impact of credit refund, total refund, and export refund on GDP the following econometric model has been applied. It associates other variables as employment and total private investment as well. With series of test on different modular forms, these variables are found to have been associated in the following form:

$$
\begin{gathered}
\text { LnGDP }_{t}=\alpha+\beta_{1} \Delta \text { LnTotRefund }_{t}+\beta_{2} \Delta \text { LnCreditRefund }_{t}+\beta_{3} \Delta \text { LnExportRefund }_{t}+\beta_{4} \text { LnEmpl }_{t} \\
+\beta_{5} \text { LnPvinv }_{t}+\epsilon_{t}
\end{gathered}
$$

Private investment is the most significant variable in explaining the variation in GDP irrespective of the other variables

${ }^{6}$ F Schneider, The Size of the Shadow Economies of 145 Countries all over the World: First Results over the Period 1999 to 2003, Discussion Paper Series, December 2004, IZA DP No. 1431, Institute for the Study of Labor, available at http://www.u4.no/document/literature/schneider-2003-size-of-shadow-economies-145-countries.pdf

7 Dhas \& Helen, "Social Security for Unorganised Workers in India", MPRA Paper No. 9247 (July 2008) available at http://mpra.ub.uni-muenchen.de/9247/1/MPRA_paper_9247.pdf and The Task Force for Statistical and Definitional Issues, National Commission for Enterprises in the Unorganised Sector, (September 2008) available at http://nceus.gov.in/Definitional_and_statistical_report.pdf

${ }^{8}$ N Eissa \& W Jack, "Tax Reform in Kenya: Policy and Administrative Issues", in Taxation in Developing Countries: Six Case Studies and Policy Implications, at p 201, ed. by R Gordon, (New York: Columbia University Press), 2010.

9 Pastrana, "The Informal Sector and Non-Regular Employment in the Philippines" available at http://www.adbi.org/conf-seminar-papers/2010/02/23/3565.non.regular.employment.philippines.paper/

${ }^{10}$ Richard M. Bird and Eric M. Zolt, "Introduction to Tax Policy Design and Development", a draft prepared for a course on Practical Issues of Tax Policy in Developing Countries, World Bank, April 28-May 1, 2003 at p.23. See http://siteresources.worldbank.org/INTTPA/Resources/BirdZoltPaper.pdf 
chosen in the model. Results are highly significant even at less than one percent level. Total refund also bears a strong positive association with GDP. When total refund is divided into credit and export refunds, the latter is found to have a significant positive impact on GDP (Table 3).

Table 3. Impact of Refunds, Employment and Private Investment on GDP, Dependent Variable: LnGDP

\begin{tabular}{llllllll}
\hline Model & $\begin{array}{l}\Delta \text { LnTot } \\
\text { Refund }\end{array}$ & $\begin{array}{l}\Delta \text { LnCredit } \\
\text { Refund }\end{array}$ & $\begin{array}{l}\Delta \text { LnExport } \\
\text { Refund }\end{array}$ & LnEmpl & LnPvtInv & Constant term & $\begin{array}{l}\text { Adjusted } \\
\mathrm{R}^{2}\end{array}$ \\
\hline 1 & & & $0.07(2.58)^{* *}$ & 0.01 & 0.93 & 4.42 & 0.98 \\
& & & $(0.97)$ & $(27.57)^{*}$ & $(11.53)^{*}$ & \\
2 & 0.10 & & & 0.01 & 0.93 & 4.47 & 0.99 \\
& $(2.60)^{* *}$ & & & $(0.92)$ & $(27.95)^{*}$ & $(11.72)^{*}$ & \\
3 & & 0.02 & & 0.03 & 0.91 & 4.51 & 0.98 \\
& & $(0.79)$ & & $(2.13)^{* *}$ & $(22.76)^{*}$ & $(9.58)^{*}$ & \\
4 & & 0.01 & 0.07 & 0.01 & 0.93 & 4.41 & 0.99 \\
& & $(0.47)$ & $(2.35)^{* *}$ & $(0.97)$ & $(26.58)^{*}$ & $(11.07)$ &
\end{tabular}

Note: Values in the parentheses are the t-statistics. ${ }^{*}$ and ${ }^{* *}$ refer the level of significance at 1 and 5 percent levels, respectively.

Agricultural activities are out of VAT net in Nepal; therefore, to be more specific, we model the regression with non-agricultural GDP as the dependent variable in the way as follows:

$$
\begin{aligned}
& \text { LnNon - agriGDP } P_{t} \\
& =\alpha+\beta_{1} \Delta \text { LnTotRefund }_{t}+\beta_{2} \Delta \text { LnCreditRefund }_{t}+\beta_{3} \Delta \text { LnExportRefund }_{t}+\beta_{4} \text { LnEmpl }_{t} \\
& +\beta_{5} \operatorname{LnPvtInv_{t}}+\epsilon_{t}
\end{aligned}
$$

Table 4. Impact of Refunds, Employment and Private Investment on Non-agricultural GDP,

Dependent Variable: $\log$ Non-agriculture GDP

\begin{tabular}{llllllll}
\hline Model & $\begin{array}{l}\Delta \text { LnTot } \\
\text { Refund }\end{array}$ & $\begin{array}{l}\Delta \text { LnCredit } \\
\text { Refund }\end{array}$ & $\begin{array}{l}\Delta \text { LnExport } \\
\text { Refund }\end{array}$ & LnEmpl & LnPvtInv & $\begin{array}{l}\text { Constant } \\
\text { term }\end{array}$ & $\begin{array}{l}\text { Adjusted } \\
\mathrm{R}^{2}\end{array}$ \\
\hline 1 & & & 0.04 & 0.01 & 0.96 & 3.79 & 0.99 \\
& & $(1.73)$ & $(0.94)$ & $(29.62)^{*}$ & $(10.33)^{*}$ & \\
2 & 0.07 & & & 0.01 & 0.96 & 3.81 & 0.99 \\
& $(1.81)^{* * *}$ & & & $(0.88)$ & $(30.28)^{*}$ & $(10.55)^{*}$ & \\
3 & & 0.02 & & 0.02 & 0.95 & 3.83 & 0.98 \\
& & $(0.98)$ & & $(1.94)^{* * *}$ & $(28.14)^{*}$ & $(9.71)^{*}$ & \\
4 & & 0.02 & 0.04 & 0.01 & 0.96 & 3.77 & 0.98 \\
& & $(0.72)$ & $(1.52)$ & $(0.98)$ & $(28.97)^{*}$ & $(10.06)^{*}$ & \\
& & & & & &
\end{tabular}

Note: Values in the parentheses are the t-statistics. *, ** and *** refer the level of significance at 1,5 , and 10 percent levels, respectively.

The impact of total refund (also divided into credit refund and export refund), level of employment, and private investment on the level of non-agricultural GDP resemble similar results as above. However, the strength of some variables has changed. The total refund has positive impact on the level of non-agricultural as well as on overall GDP. Most importantly, when total refund is divided into credit and export refund, the export refund does not have impact on the level of non-agricultural GDP referring that export refund has significant impact only on the agricultural export. Likewise, the impact of private investment is stronger in explaining the variation in non-agricultural GDP (Table 4) compared to overall GDP (Table 3).

\subsection{Correlates of Economic Growth, C-efficiency Ratio, and VAT Expansion: Models and Results}

The efficiency in the revenue system of the government can be measured by various means. In case of the consumption taxes, for example VAT, the most frequently used tool is the C-Efficiency Ratio-defined as the ratio of the VAT revenue to consumption divided by the standard tax rate. Furthermore, two strands of thought are apparent in using the consumption expenditure-overall consumption expenditure or private consumption expenditure; the latter is considered in case public consumption expenditures are all free from value added tax. 
This study has used both approaches in estimating the C-Efficiency Ratio in case of Nepalese VAT revenue system. The trend of the ratio over the entire period of VAT implementation has been shown in Figure 8. However, both approaches reveal similar trend in Nepal with only scale differences. While taking the private consumption, the ratio has reached to 0.9 in 2013/14; whereas the ratio looks far below when used total consumption expenditure. The ratio has sustainable upward trend since the fiscal year 2006/07 signifying the efficiency gain in VAT administration. Year 2006 was a landmark in Nepalese political history in ending the decade-long armed conflict; therefore, the implication can be drawn that many transactions once unable to appear in the formal trading route began appearing through the expected track, thus, improving the revenue performance of the government.

Following the first definition, i.e. using total consumption expenditure, Nepal's VAT C-Efficiency Ratio is quite low in the range of 0.3 to 0.35 compared to the world's average of 0.45 in 2005 . The same ratio was found to be 0.67 for Japan, 0.94 for New Zealand, and 0.54 for OECD countries (Ahmad \& Faris, 2010). This shows Nepal still having a long way to go through the VAT efficiency improvement.



Figure 8. C-Efficiency Ratio of VAT in Nepal

Variation in C-efficiency ratio depends on various factors; however, studies show some variables affect this ratio more than others. Most importantly, proportion of urban population, degree of trade openness, level of Gross Domestic Product (GDP), level of non-agricultural GDP, proportion of budget deficit in total government expenditure, VAT Gap as a proportion of potential VAT revenue, etc. affect the C-efficiency significantly. Here, we test the impact of these variables on C-efficiency of VAT collection in case of Nepal.

$C-$ efficiency ratio $_{t}=$

$\alpha+\beta_{1}$ Urban pop ratio $_{t}+\beta_{2}$ Trade openess ratio $_{t}+\beta_{3} \Delta$ LnGDP $_{t}+\beta_{4} \Delta$ LnNonagri GDP $_{t}+$

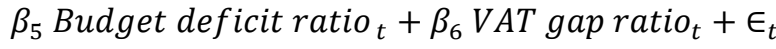

Where,

Urban pop ratio $=$ proportion of urban population in total population,

Trade openness $=($ import + export $) /$ GDP,

$\Delta \mathrm{LnGDP}=$ change in natural log of GDP,

$\Delta \mathrm{LnNonagri}$ GDP $=$ change in natural log of non-agricultural GDP,

Budget deficit ratio = budget deficit as a proportion of government expenditure,

VAT gap ratio = VAT gap as a proportion of potential VAT revenue,

$\mathrm{t}$ is the time subscript.

$\alpha$ is the constant term in the regression, and

$\epsilon$ is the residual.

Urban population, trade openness, GDP, non-agricultural GDP are expected to contribute positively to C-efficiency ratio; whereas budget deficit and VAT gap are expected to impact negatively on the C-efficiency ratio. 
Urbanization contributes positively to C-efficiency ratio; however, if the effects of trade openness and growth of non-agricultural GDP are accounted urbanization no longer becomes significant in this regard. Furthermore, between the two significant variables - trade openness and non-agricultural GDP - the latter is even more significant as evident from model 4 and 5 in Table 5.

Table 5. Impact of urbanization, trade openness, GDP, budget deficit, and VAT gap on C-efficiency Dependent variable: C-efficiency ratio (using total consumption expenditure)

\begin{tabular}{|c|c|c|c|c|c|c|c|c|c|}
\hline Model & $\begin{array}{l}\text { Urban pop } \\
\text { ratio }\end{array}$ & $\begin{array}{l}\text { VAT } \\
\text { ratio }\end{array}$ & gap & $\Delta$ LnGDP & $\begin{array}{l}\Delta \mathrm{Ln} \\
\text { Non-agri } \\
\text { GDP }\end{array}$ & $\begin{array}{l}\text { Budget } \\
\text { deficit ratio }\end{array}$ & $\begin{array}{l}\text { Trade } \\
\text { openness } \\
\text { ratio }\end{array}$ & $\begin{array}{l}\text { Constant } \\
\text { term }\end{array}$ & $\begin{array}{l}\text { Adjusted } \\
\mathrm{R}^{2}\end{array}$ \\
\hline 1 & $\begin{array}{l}2.71 \\
(3.72)^{*}\end{array}$ & & & & $\begin{array}{l}0.038 \\
(2.38)\end{array}$ & $\begin{array}{l}-0.32 \\
(-1.32)\end{array}$ & & $\begin{array}{l}-0.15 \\
(-0.99)\end{array}$ & 0.48 \\
\hline 2 & $\begin{array}{l}2.01 \\
(3.91)^{*}\end{array}$ & & & & $\begin{array}{l}.036 \\
(2.19)\end{array}$ & & & $\begin{array}{l}0.025 \\
(0.32)\end{array}$ & 0.45 \\
\hline 3 & $\begin{array}{l}.84 \\
(1.21)\end{array}$ & $\begin{array}{l}-0.51 \\
(-2.21)^{*}\end{array}$ & & & $\begin{array}{l}.038 \\
(2.63)^{*}\end{array}$ & & & $\begin{array}{l}0.45 \\
(2.20)\end{array}$ & 0.57 \\
\hline 4 & $\begin{array}{l}1.70 \\
(1.68)\end{array}$ & $\begin{array}{l}-0.21 \\
(-0.75)\end{array}$ & & & & & $\begin{array}{l}0.86 \\
(1.86)^{* *}\end{array}$ & $\begin{array}{l}-.127 \\
(-0.31)\end{array}$ & 0.48 \\
\hline 5 & $\begin{array}{l}1.37 \\
(1.45)\end{array}$ & $\begin{array}{l}-0.38 \\
(-1.37)\end{array}$ & & & $\begin{array}{l}.031 \\
(1.83)^{*}\end{array}$ & & $\begin{array}{l}0.412 \\
(0.83)\end{array}$ & $\begin{array}{l}0.16 \\
(0.40)\end{array}$ & 0.56 \\
\hline 6 & & $\begin{array}{l}-0.73 \\
(-4.71)^{*}\end{array}$ & & & $\begin{array}{l}0.034 \\
(2.37)^{*}\end{array}$ & & & $\begin{array}{l}0.68 \\
(9.15)^{*}\end{array}$ & 0.56 \\
\hline 7 & & $\begin{array}{l}-0.62 \\
(-3.70)^{*}\end{array}$ & & & & & $\begin{array}{l}0.33 \\
(0.93)\end{array}$ & $\begin{array}{l}0.520 \\
(3.72)\end{array}$ & 0.42 \\
\hline 8 & $\begin{array}{l}1.90 \\
(3.27)^{*}\end{array}$ & & & $\begin{array}{l}0.13 \\
(0.60)\end{array}$ & & & & $\begin{array}{l}-2.73 \\
(-5.34)\end{array}$ & 0.77 \\
\hline 9 & $\begin{array}{l}0.84 \\
(1.16)\end{array}$ & $\begin{array}{l}-0.51 \\
(-2.05)^{*}\end{array}$ & & $\begin{array}{l}0.041 \\
(0.19)\end{array}$ & & & & $\begin{array}{l}0.45 \\
(2.07)\end{array}$ & 0.56 \\
\hline
\end{tabular}

${ }^{*}$ refers to five percent level of significance. ${ }^{* *}$ refers to ten percent level of significance.

We have covered the whole period of 17 years (1997/98-2013/14 to which the final data are available) of VAT implementation in Nepal. When applied this model with several combinations of the variables discussed have yield the results as presented in Table 5. Trade openness definitely has positive impact on C-efficiency ratio. As almost two-thirds of Nepalese VAT revenue is import based, the trade openness apparently raises the VAT collection efficiency provided that the informal trade is controlled that eventually improves the efficiency of VAT collection.

Nepal's GDP and non-agricultural GDP are growing at unison; both of them bear positive association with the VAT C-efficiency ratio. Regression analysis reveals that non-agricultural GDP has strong influence to VAT C-efficiency ratio. On the other hand, budget deficit does not have much influence to this ratio rather its effect is captured by the VAT gap; higher the VAT gap, lower is the C-efficiency ratio.

In summarizing, in case of Nepal, growth of the non-agricultural GDP and relative share of VAT gap in total VAT potential explain a large variation in C-efficiency ratio followed by trade openness and ratio of urbanization. 
Table 6. Impact of urbanization, trade openness, GDP, budget deficit, and VAT gap on C-efficiency ratio, Dependent variable: C-efficiency ratio (using private consumption expenditure)

\begin{tabular}{|c|c|c|c|c|c|c|c|c|}
\hline Model & $\begin{array}{l}\text { Urban pop } \\
\text { ratio }\end{array}$ & $\begin{array}{l}\text { VAT gap } \\
\text { ratio }\end{array}$ & $\Delta$ LnGDP & $\begin{array}{l}\Delta \text { Ln Non-agri } \\
\text { GDP }\end{array}$ & $\begin{array}{l}\text { Budget } \\
\text { deficit ratio }\end{array}$ & $\begin{array}{l}\text { Trade } \\
\text { openness } \\
\text { ratio }\end{array}$ & $\begin{array}{l}\text { Constant } \\
\text { term }\end{array}$ & $\begin{array}{l}\text { Adjusted } \\
\mathrm{R}^{2}\end{array}$ \\
\hline 1 & $\begin{array}{l}3.42 \\
(4.05)^{*}\end{array}$ & & & $\begin{array}{l}0.045 \\
(2.40)^{*}\end{array}$ & $\begin{array}{r}-0.37 \\
(-1.33)\end{array}$ & & $\begin{array}{l}-0.23 \\
(-1.26)\end{array}$ & 0.54 \\
\hline 2 & $\begin{array}{l}2.60 \\
(4.36)^{*}\end{array}$ & & & $\begin{array}{l}0.042 \\
(2.21)^{*}\end{array}$ & & & $\begin{array}{l}-0.019 \\
(-0.21)\end{array}$ & 0.51 \\
\hline 3 & $\begin{array}{l}1.22 \\
(1.52)\end{array}$ & $\begin{array}{l}-.61 \\
(-2.25)^{*}\end{array}$ & & $\begin{array}{l}0.045 \\
(2.67) *\end{array}$ & & & $\begin{array}{l}0.48 \\
(2.04)^{*}\end{array}$ & 0.62 \\
\hline 4 & $\begin{array}{l}2.19 \\
(1.85)^{* *}\end{array}$ & $\begin{array}{l}-.266 \\
(-0.79)\end{array}$ & & & & $\begin{array}{l}0.98 \\
(1.82) * *\end{array}$ & $\begin{array}{l}-0.17 \\
(-0.37)\end{array}$ & 0.53 \\
\hline 5 & $\begin{array}{l}1.80 \\
(1.64)\end{array}$ & $\begin{array}{l}-0.46 \\
(-1.43)\end{array}$ & & $\begin{array}{l}0.037 \\
(1.89)^{* *}\end{array}$ & & $\begin{array}{l}.44 \\
(0.78)\end{array}$ & $0.16(0.36)$ & 0.61 \\
\hline 6 & & & $\begin{array}{l}0.47 \\
(1.39)\end{array}$ & & $\begin{array}{l}0.37 \\
(1.32)\end{array}$ & & $0.41(5.02)^{*}$ & 0.14 \\
\hline 7 & & $\begin{array}{l}-0.791 \\
(-3.93)^{*}\end{array}$ & & & & $0.30(0.71)$ & $\begin{array}{l}.65 \\
(3.95)^{*}\end{array}$ & 0.45 \\
\hline 8 & $\begin{array}{l}2.46 \\
(3.65)^{*}\end{array}$ & & $\begin{array}{l}.180 \\
(0.66)\end{array}$ & & & & $\begin{array}{l}-.01 \\
(-0.13)\end{array}$ & 0.52 \\
\hline 9 & $\begin{array}{l}1.22 \\
(1.44)\end{array}$ & $\begin{array}{l}-0.59 \\
(-2.08) * *\end{array}$ & $\begin{array}{l}0.06 \\
(0.26) \\
\end{array}$ & & & & $\begin{array}{l}0.48 \\
(1.91) \\
\end{array}$ & 0.61 \\
\hline
\end{tabular}

five percent level of significance, ${ }^{* *}$ ten percent level of significance

In a bit different front, using private consumption expenditure instead of total (Table 6), the results are quite similar. Therefore, comparison of the results between Table 5 and 6 has helped us in checking the robustness of the results and they have reinforced the conclusion and implications of the analysis.

\section{Conclusion and Policy Implications}

The role of VAT is crucial in many developing countries because of the impact on economic decision making of households and businesses than income tax has. To be more specific, it has less impact on saving and investment; therefore, might not distort capital formation and growth of the economy. In many developing countries, custom duties still constitute a big chunk in domestic tax revenue; therefore, it should also improve for the high VAT compliance because the biggest part of the VAT revenue is import based in many countries. In the wake of trade liberalization, the rate of import duties are bound to decline in coming years; however, studies show the VAT possessing more revenue potential in replacing the lost custom tax revenue (Acharya, 2012; and Acharya, 2011) of developing world. Over the years, Nepal's VAT composition shows declining contribution of VAT from production activities and increasing contribution from sales, distribution, contract and consultancy services. This rather discouraging trend reflects the productivity of manufacturing sector declining and that of distribution activities growing. Effective exemption or refund or differential VAT rate or a combination of them may require for reversing the trend mentioned.

From the fundamental economics, exemption has dual benefits: first, it helps maintain the standard tax rate high and partly can make indirect tax as well progressive one. Second, it makes the possibility of applying single VAT rate. Therefore, provision of exemption should have logical and scientific bases instead of political one. Gradual extension of the exemption items reveals weaknesses in Nepalese VAT system and this requires effective control.

Shifting micro-enterprises to presumptive tax would greatly simplify VAT system in developing world because of five reasons. First, it develops the book keeping habits of the sellers; second, VAT administration does not have adequate human resource to meet the growing number of micro entrepreneurs; therefore, presumptive tax can be the solution for the short run. Third, if the micro enterprises are fully shifted to presumptive VAT, high compliance cost is expected to decline. Fourth, this will control the issuance of fake bills and VAT fraud. Fifth, the VAT audit will be effective in the tax offices with the available manpower of tax officers/auditors.

Extension of the exemption items from VAT imposition has become a part and parcel of the Nepalese VAT system. Most initial exemptions complied with that of many other developing countries and included the primary products of the agricultural sector, medicine and health services, basic necessities such as kerosene and other fuel items, education, financial and insurance services. The products were expanded and in successive years included electricity, machinery and various inputs such as those used by hydro-power projects, certain industrial equipment, etc. Furthermore, partial exemptions (less than 100 percent) have been applied to some products such as textiles, matches, tire tubes, flour, mustard oil, mobile phones, and sugar. Exemption has also reached to the expenses on travel, gold and silver, mobile phone, and even gambling. This is recommended to make revision of the exemption items periodically otherwise the 
creation of arrear will push the VAT efficiency and productivity downward chasing only few goods and services for the VAT net.

The VAT refund system has impact on the level of GDP. Econometric analysis reveals that export refund has significant impact on the level of GDP, more specifically on agricultural activities. Nepalese VAT system; therefore, requires to have refund facility more focused on agricultural export. Furthermore, the impact is stronger if it is associated with growing private investment.

Estimation of C-efficiency ratio and studying its variations with reference to urbanization, non-agricultural as well as total GDP, trade openness, VAT gap, and budget deficit have produced some interesting findings. C-efficiency ratio is improving in Nepalese VAT, especially after fiscal year 2006/07. Urbanization has contributed positively to C-efficiency ratio; however, if the effects of trade openness and growth of non-agricultural GDP are accounted, urbanization is no longer significant. Furthermore, non-agricultural GDP is more significant in explaining the variation in C-efficiency of Nepalese VAT.

Trade openness definitely has positive impact on C-efficiency ratio. As almost two-thirds of Nepalese VAT revenue is import based, the trade openness apparently raises the VAT collection efficiency provided that the informal trade is controlled. Likewise, GDP growth, more specifically non-agricultural GDP, has strong influence to VAT C-efficiency ratio. On the other hand, budget deficit does not have much influence to this ratio rather its effect is captured by the VAT gap. Higher the VAT gap, lower is the C-efficiency ratio.

\section{References}

Acharya, B. P., \& Dhakal, M. P. (2011). Assessment of VAT Evasion in Nepal. Kathmandu: World Bank.

Acharya, S. (2010). Import liberalisation and revenue replacement: impacts in a small Asian developing economy. European Journal of Development Research, (22), 417-442. http://dx.doi.org/10.1057/ejdr.2010.4

Acharya, S. (2012). Pro-poor Growth and Liberalisation in Developing Economies. London: Routledge.

Ahmad, E., \& Faris, A. A. (2010). Fiscal Reform in Middle East: VAT in the Gulf Co-operation Council. Edward Elgar Publishing. http://dx.doi.org/10.4337/9781849805827

Gambia Revenue Authority. (2014). VAT Revenue Guide.

Elgin, C., \& Oyvat, C. (2013). Lurking in the cities: Urbanization and the informal economy. Structural Change and Economic Dynamics (27), 36-47. http://dx.doi.org/10.1016/j.strueco.2013.06.003

Eric, H. M. T. (2014). Revenue Administration Gap Analysis Program-The Value-Added Tax Gap. International Monetary Fund.

Gautam, D. K. (2014). Value Added Tax: Existing Condition and Issues to be improved. Kathmandu: Inland Revenue Department.

Inland Revenue Department . (2012). Strategic Plan 2012/13-2016/17. IRD, Kathmandu.

Jalata, D. M. (2014). The Role of Value Added Tax on Economic Growth of Ethiopia. Science, Technology and Arts Research Journal (3(1)), 156-151. http://dx.doi.org/10.4314/star.v3i1.26

Khadka, R. (2004). Value Added Tax in Nepal: Challenges and Prospects for Resource Mobilization . Kirtipur, Kathmandu : New Hira Books Enterprises.

Lejeune, I. (2011). The EU VAT Experience: What Are the Lessons? In The VAT Reader (pp. 257-282). Tax Analysts.

Owens, J., \& Battiau, P. (2011). VAT's next half century: Towards a single-rate system? OECD Observer, 289 (Q1).

Phua, S. (2011). Tax Gap: Causes and Solutions. New Delhi: Indian Council for Research on International Economic Relations.

Rouf, M. A. (2015, April 30). Reduced VAT rates distort the system. The Financial Express Bangladesh.

Sharma, D. R., \& Sarker, T. (2014). Weakness of VAT in Nepal. IBFD.

Smith, A. M., Islam, A., \& Moniruzzaman, M. (2011). Consumption Taxes in Developing Countries -- The Case of Bangladesh VAT (Vol. 82). Wellington: Centre for Accounting, Governance and Taxation Research, School of Accounting and Commercial Law, Victoria University of Wellington.

Shome, P. (2006). The control of tax evasion and the role of tax administration, L Bernardi et al. (Ed.), Tax Systems and Tax Reforms in South and East Asia, Routledge: New York. 
Annex:

Annex A1

Table A1: Trend of VAT refund (values in Rupees)

\begin{tabular}{llll}
\hline Fiscal Year & Export & Credit & Total Refund \\
\hline $1997 / 98$ & 0 & 0 & - \\
$1998 / 99$ & $14,573,686$ & $44,971,706$ & $59,545,392$ \\
$1999 / 00$ & $252,312,510$ & $116,658,225$ & $368,970,735$ \\
$2000 / 01$ & $880,231,138$ & $121,155,057$ & $1,001,386,195$ \\
$2001 / 02$ & $1,465,714,323$ & $152,671,359$ & $1,618,385,682$ \\
$2002 / 03$ & $1,347,365,673$ & $64,138,799$ & $1,411,504,472$ \\
$2003 / 04$ & $1,890,494,847$ & $160,157,342$ & $2,050,652,189$ \\
$2004 / 05$ & $2,513,356,869$ & $240,726,086$ & $2,754,082,955$ \\
$2005 / 06$ & $3,397,107,561$ & $478,576,850$ & $3,875,684,411$ \\
$2006 / 07$ & $3,071,920,477$ & $973,065,739$ & $4,044,986,216$ \\
$2007 / 08$ & $2,179,027,926$ & $432,214,752$ & $2,611,242,678$ \\
$2008 / 09$ & $1,062,798,919$ & $1,848,775,944$ & $2,911,574,863$ \\
$2009 / 10$ & $1,209,702,321$ & $881,098,778$ & $2,090,801,099$ \\
$2010 / 11$ & $1,740,160,811$ & $1,830,675,727$ & $3,570,836,538$ \\
$2011 / 12$ & $1,849,947,062$ & $2,702,102,852$ & $4,552,049,914$ \\
$2012 / 13$ & $2,104,631,671$ & $4,203,268,927$ & $6,307,900,598$ \\
$2013 / 14$ & $2,340,615,513$ & $3,759,289,818$ & $6,099,905,331$ \\
\hline
\end{tabular}

Annex A2: Total deduction and addition in VAT gap

Total deduction consists of whole or partial expenses concerning gross fixed capital formation, change in stock, lodge services, real estate income, renting and business activities, electricity, gas and water, financial intermediation, private basic consumption, manufacturing, domestic retail trade, and kerosene.

The values exempted above are, in fact, not to be exempted to a fuller extent. In some of the cases, the percentages are specified for the deduction; however, in other cases, we need to be specific to make additions if they were fully deducted. The components needed for additions are value of input in change in stock, part of the GFCF that is required for value added in cottage, small, and medium level industries, and inputs for legal and commercial services.

Based on these deductions and additions, we estimate the VAT base and apply standard VAT rate to get VAT potential. The difference between the latter and the actual VAT collection yields VAT gap. Table 9 also presents the VAT gap as a percentage of total VAT collection.

Table A2. VAT base, VAT potential, VAT collection, and VAT gap

\begin{tabular}{|c|c|c|c|c|c|c|c|c|c|}
\hline Fiscal Year & Total Transaction (A) & $\begin{array}{l}\text { Total } \\
\text { Deduction } \\
\text { (B) }\end{array}$ & $\begin{array}{l}\text { Addition } \\
\text { (C) }\end{array}$ & $\begin{array}{l}\text { VAT Base } \\
\text { A-B+C }\end{array}$ & $\begin{array}{l}\text { Standard } \\
\text { Rate }\end{array}$ & $\begin{array}{l}\text { VAT } \\
\text { Potential }\end{array}$ & $\begin{array}{l}\text { VAT } \\
\text { Collection }\end{array}$ & $\begin{array}{l}\text { VAT } \\
\text { GAP }\end{array}$ & $\begin{array}{l}\text { VAT } \\
\text { GAP } \\
(\% \\
\text { VAT of } \\
\text { collection) }\end{array}$ \\
\hline $1997 / 98$ & 33413.5 & 19614.03 & 2848.835 & 16648.30 & 10.00 & 1664.83 & 712.26 & 952.57 & 57.22 \\
\hline $1998 / 99$ & 36553.4 & 20719.83 & 2566.103 & 18399.68 & 10.00 & 1839.97 & 876.59 & 963.38 & 52.36 \\
\hline $1999 / 00$ & 41418.3 & 24295.13 & 3762.583 & 20885.75 & 10.00 & 2088.57 & 1025.97 & 1062.60 & 50.88 \\
\hline $2000 / 01$ & 48866.6 & 28426.54 & 3791.739 & 24231.80 & 10.00 & 2423.18 & 1238.24 & 1184.94 & 48.90 \\
\hline $2001 / 02$ & 50886.2 & 29000.44 & 3262.525 & 25148.29 & 10.00 & 2514.83 & 1226.73 & 1288.10 & 51.22 \\
\hline $2002 / 03$ & 55547.3 & 31787.72 & 3806.093 & 27565.67 & 10.00 & 2756.57 & 1345.97 & 1410.60 & 51.17 \\
\hline $2003 / 04$ & 60535.6 & 35432.46 & 5155.531 & 30258.68 & 10.00 & 3025.87 & 1447.89 & 1577.98 & 52.15 \\
\hline $2004 / 05$ & 67720.8 & 40716.47 & 6501.378 & 33505.71 & 11.65 & 3903.42 & 1888.54 & 2014.88 & 51.62 \\
\hline $2005 / 06$ & 77096 & 47068.82 & 7243.799 & 37270.98 & 13.00 & 4845.23 & 2161.49 & 2683.74 & 55.39 \\
\hline $2006 / 07$ & 86515.3 & 54174.89 & 8864.469 & 41204.87 & 13.00 & 5356.63 & 2609.56 & 2747.07 & 51.28 \\
\hline $2007 / 08$ & 98274.2 & 61294.06 & 10552.14 & 47532.28 & 13.00 & 6179.20 & 2981.57 & 3197.63 & 51.75 \\
\hline 2008/09 & 120785.2 & 74077.91 & 13790.72 & 60498.02 & 13.00 & 7864.74 & 3970.09 & 3894.65 & 49.52 \\
\hline $2009 / 10$ & 149601.7 & 95848.22 & 21399.28 & 75152.76 & 13.00 & 9769.86 & 5492.09 & 4277.77 & 43.79 \\
\hline 2010/11 & 169529.8 & 107857.09 & 24623.51 & 86296.22 & 13.00 & 11218.51 & 6166.36 & 5052.15 & 45.03 \\
\hline $2011 / 12$ & 188642.8 & 116758.95 & 24396.75 & 96280.59 & 13.00 & 12516.48 & $7,093.04$ & 5423.44 & 43.33 \\
\hline $2012 / 13$ & 214636.1 & 134618.12 & 28683.81 & 108701.80 & 13.00 & 14131.23 & 8341.84 & 5789.39 & 40.97 \\
\hline $2013 / 14$ & 247154.1 & 152359.94 & 32510.95 & 127305.11 & 13.00 & 16549.66 & $10,305.94$ & 6243.73 & 37.73 \\
\hline
\end{tabular}

Source: Author's own estimation. 


\section{Annex B: Scatter plots of regression results}

\section{Growth Equations}

Impact of credit, export and total refund, employment growth, and private investment on Non-agricultural GDP

Model 1

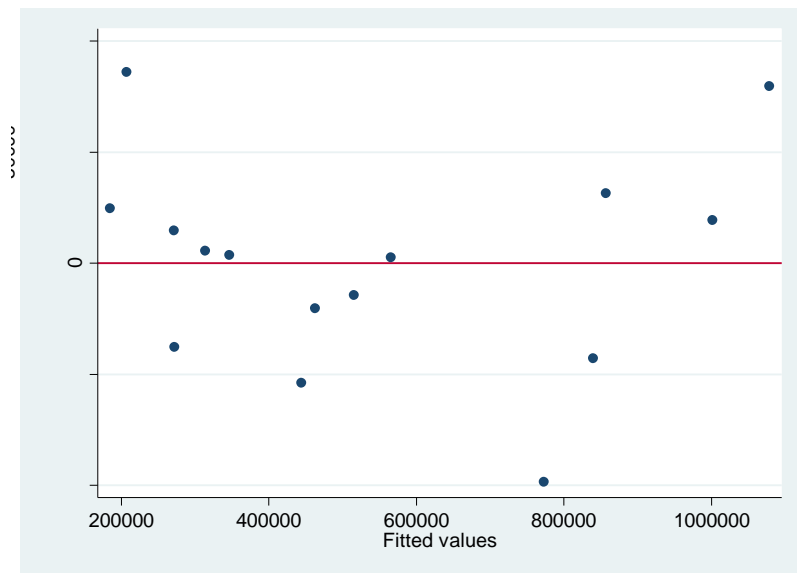

Model 3

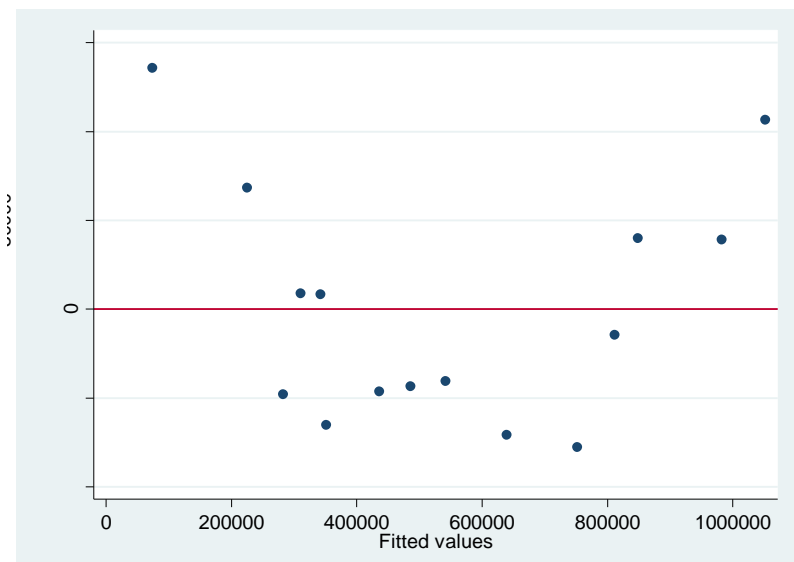

Model 2

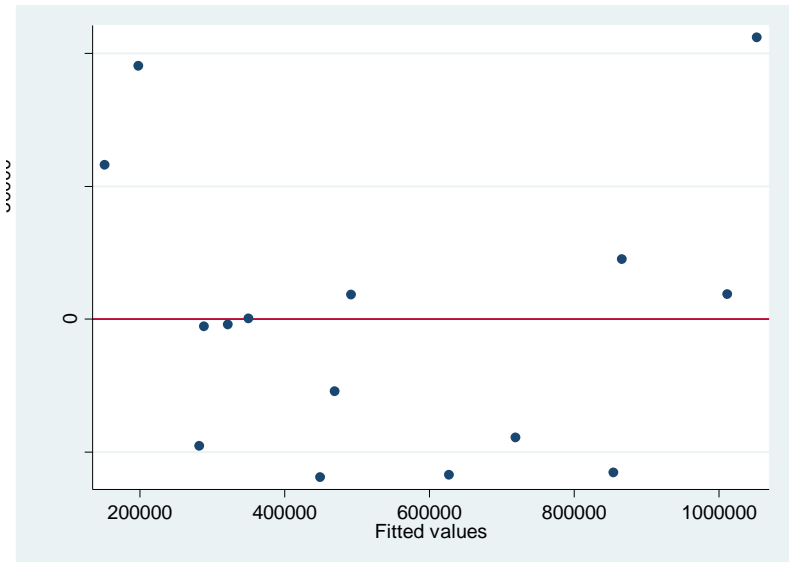

Model 4

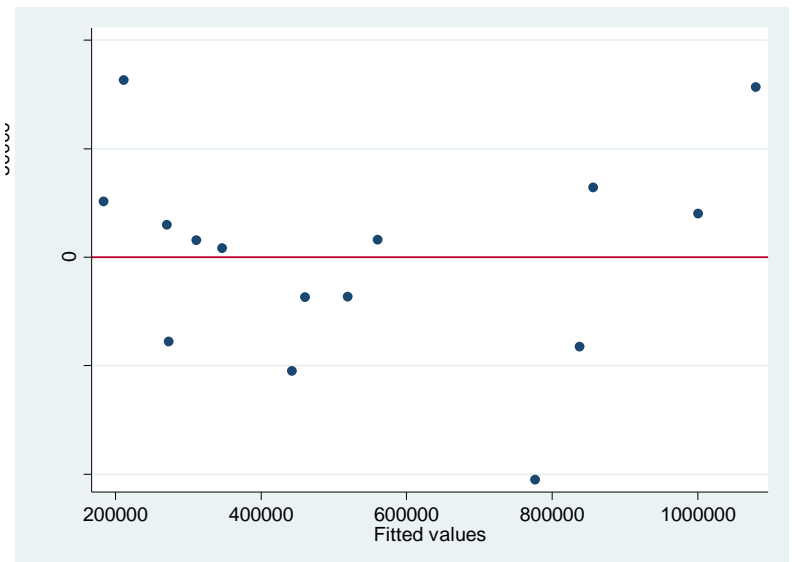


Residuals plots -2

Impact of credit, export and total refund, employment growth, and private investment on GDP

Model 1

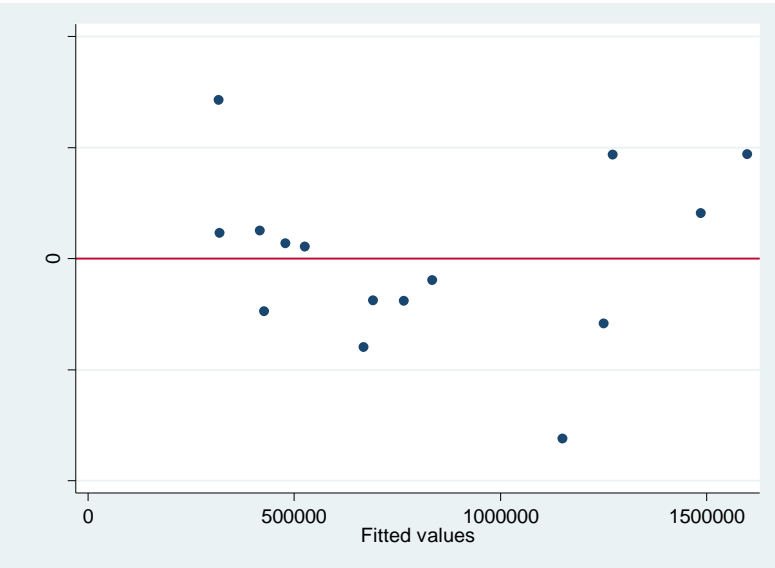

Model 3

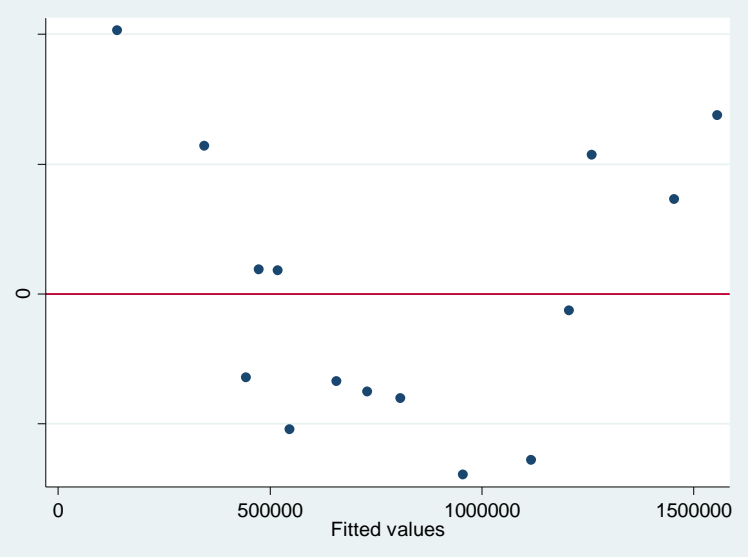

Model 2

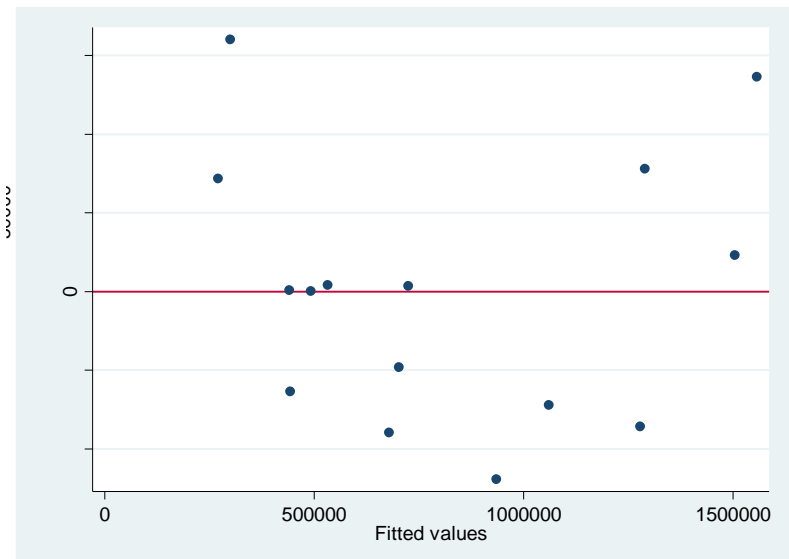

Model 4

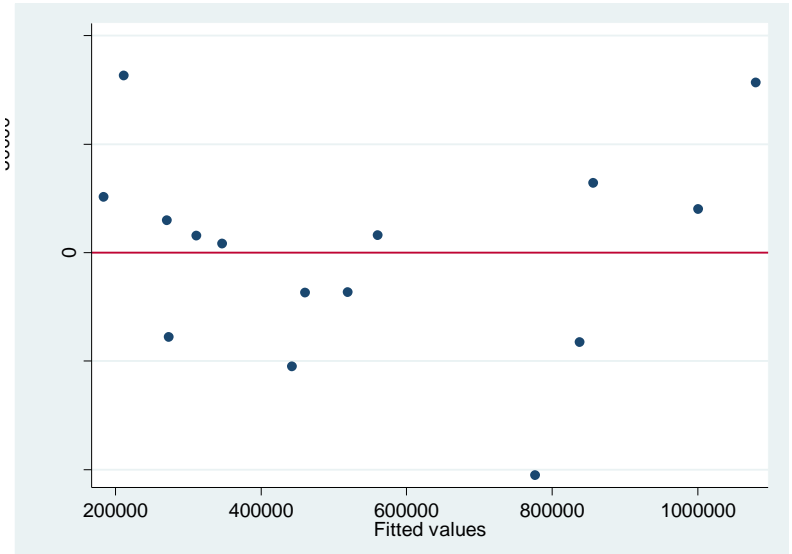




\section{C-efficiency Ratio Equations}

\section{Residual Plots 1}

Residuals from the regressions summarized in Table 5

Model 1

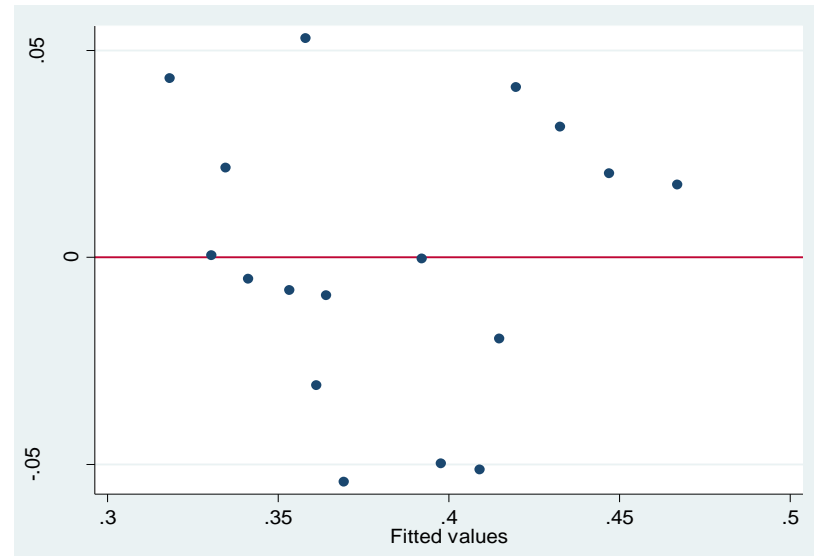

Model 3

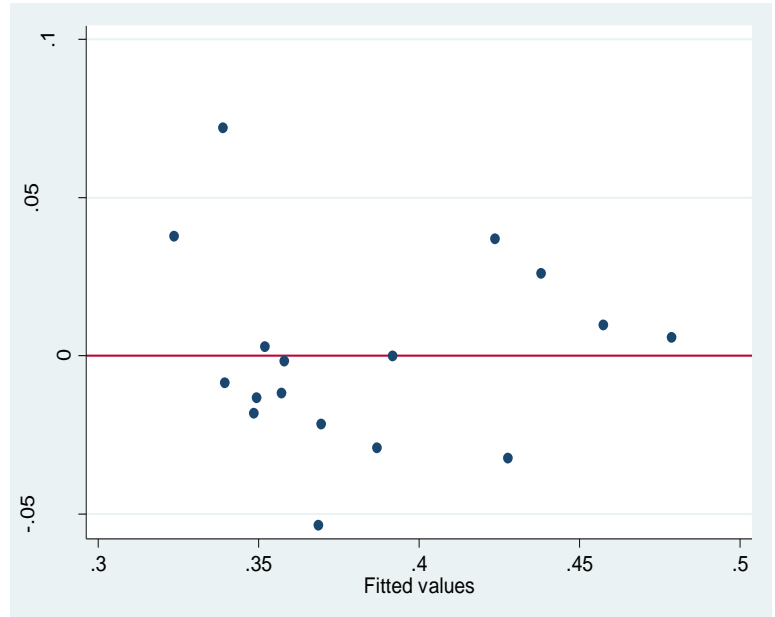

Model 5

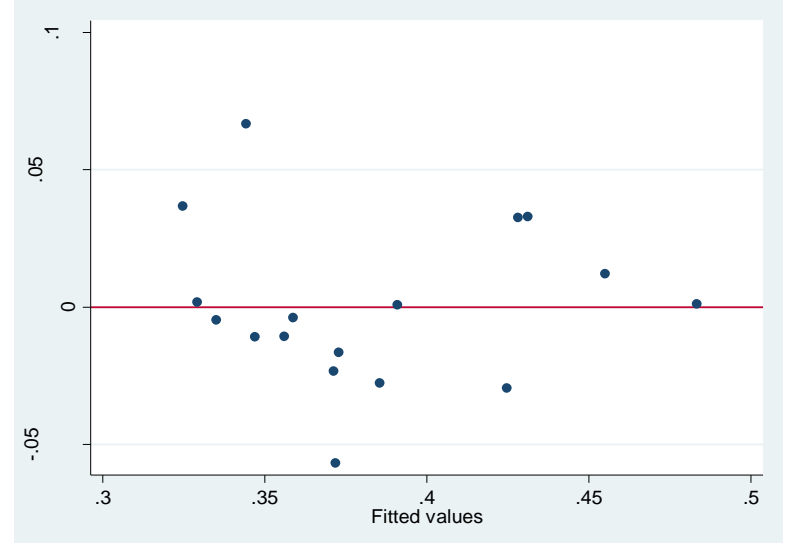

Model 2

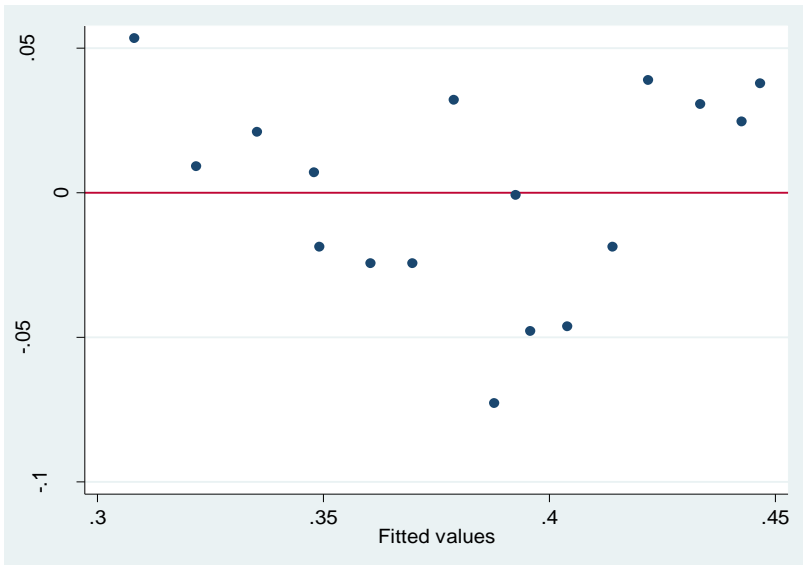

Model 4

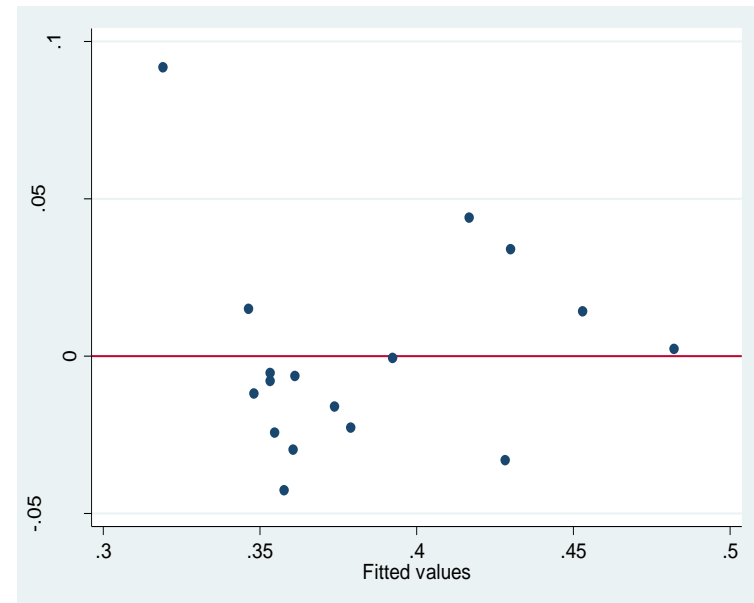

Model 6

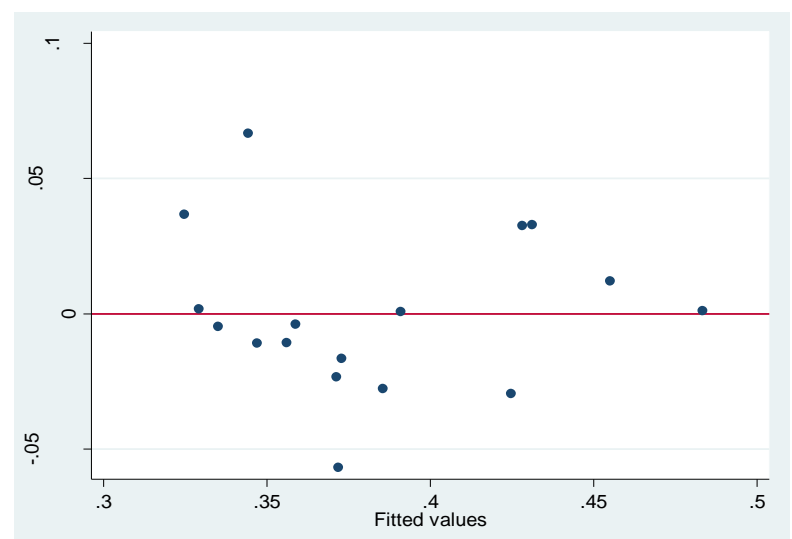


Model 7

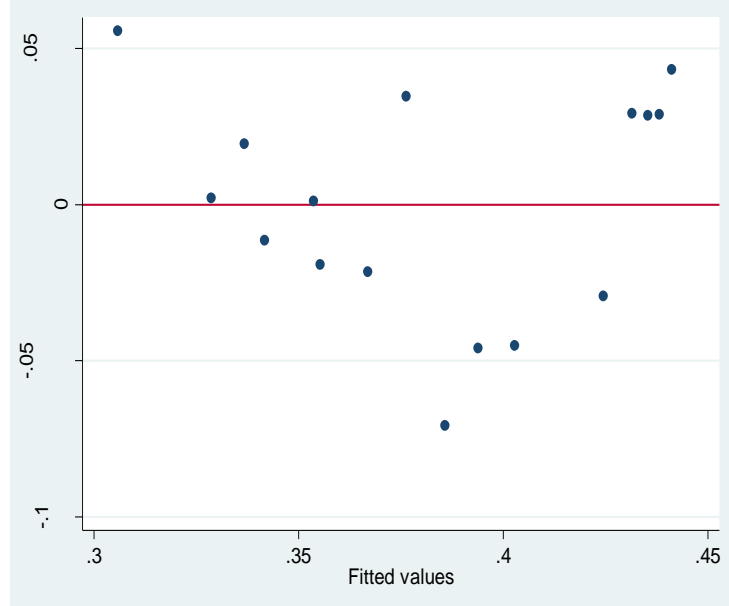

Model 9

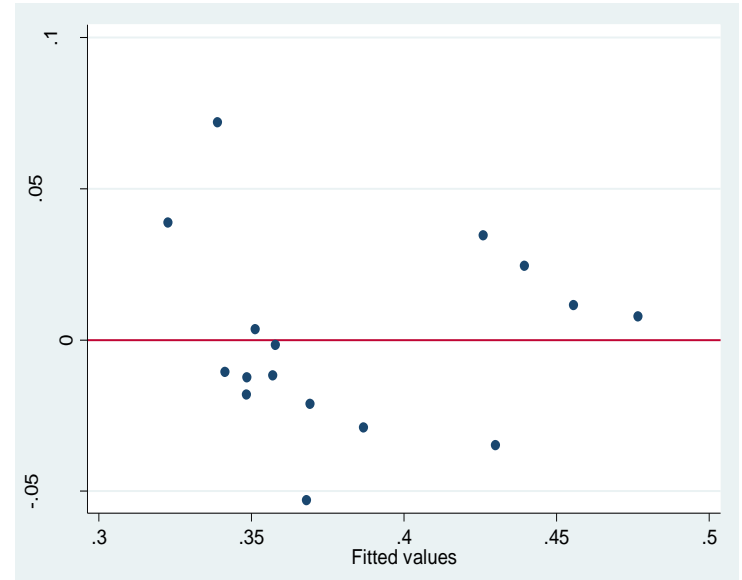

Model 8

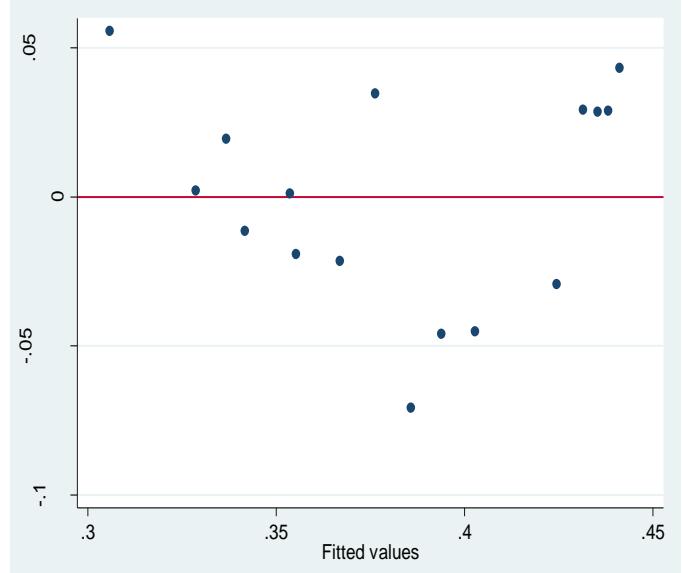




\section{Residual Plots 2}

Residuals from the regressions summarized in Table 6

Model 1

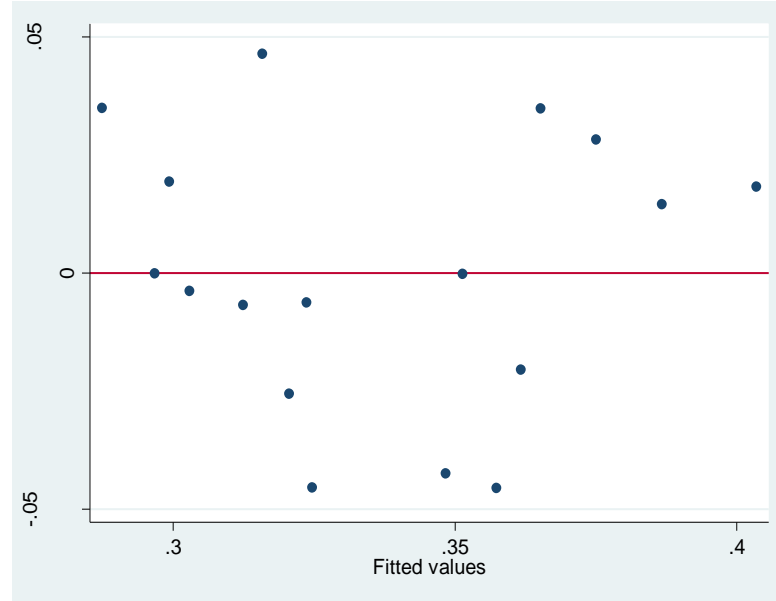

Model 3

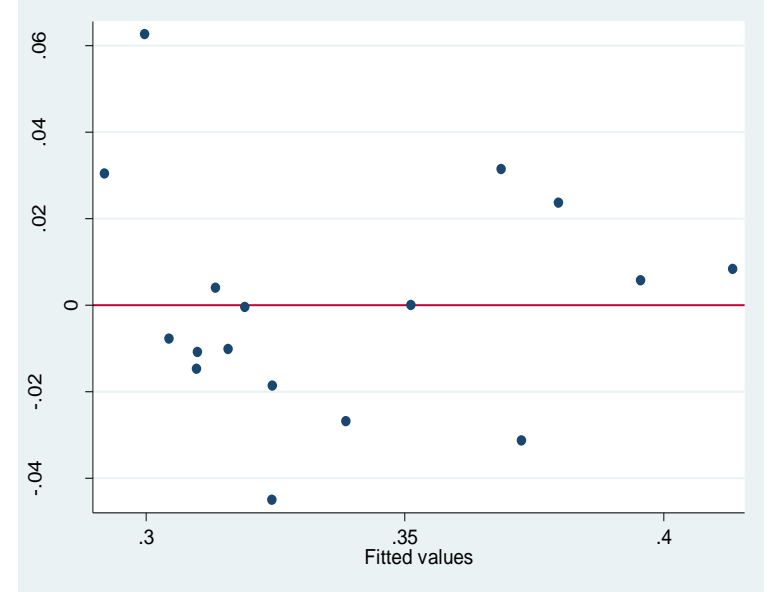

Model 2

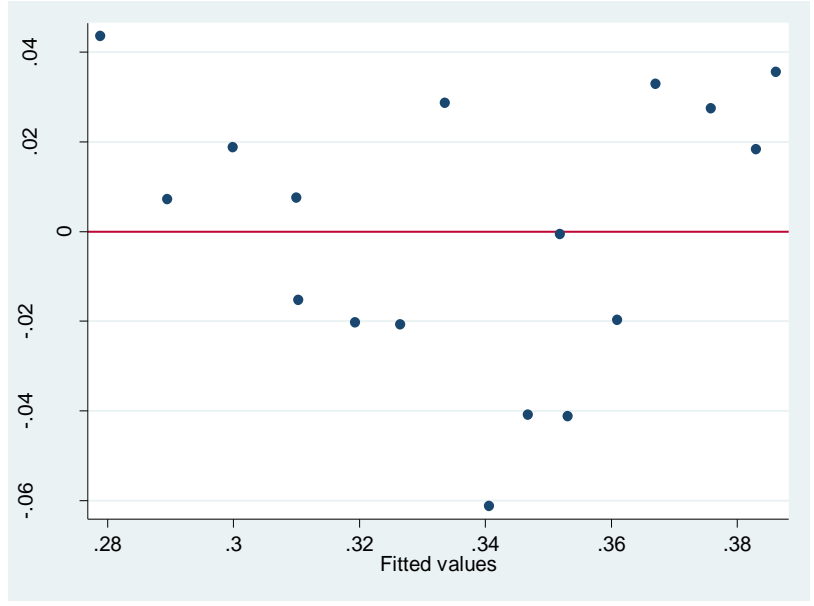

Model 4




Model 5
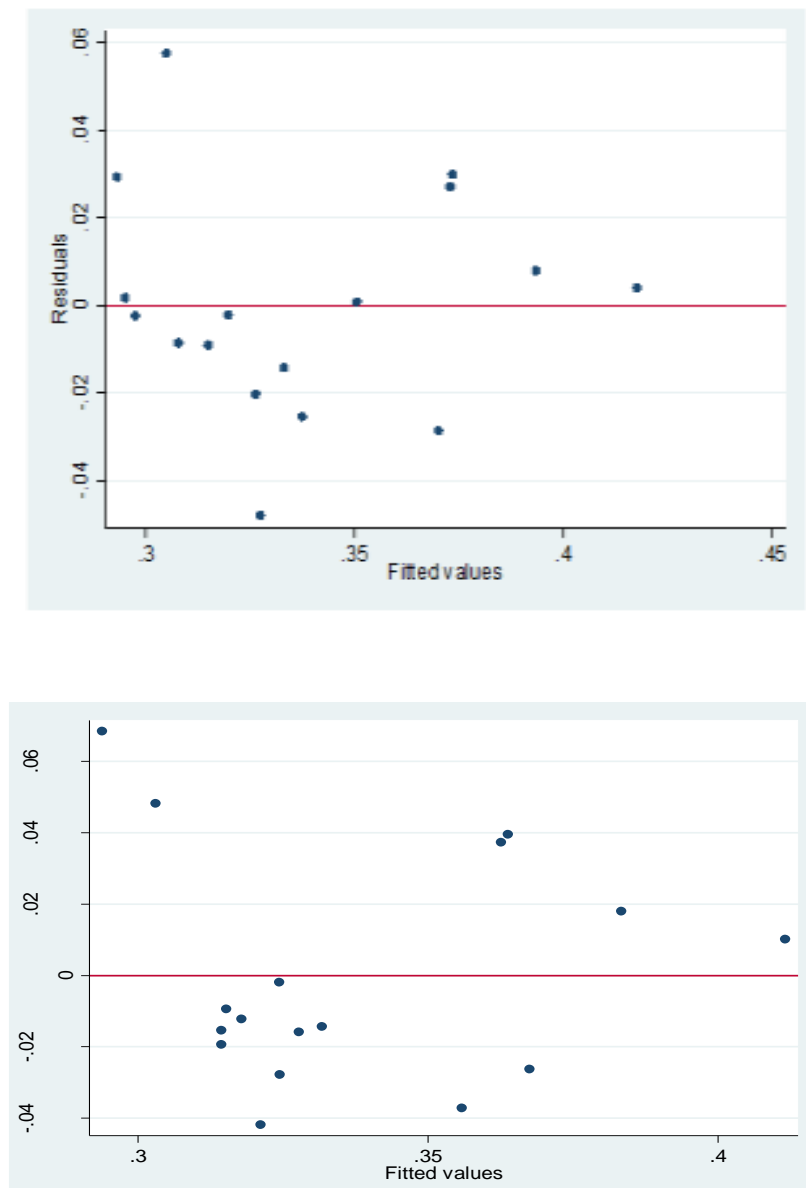

Model 7

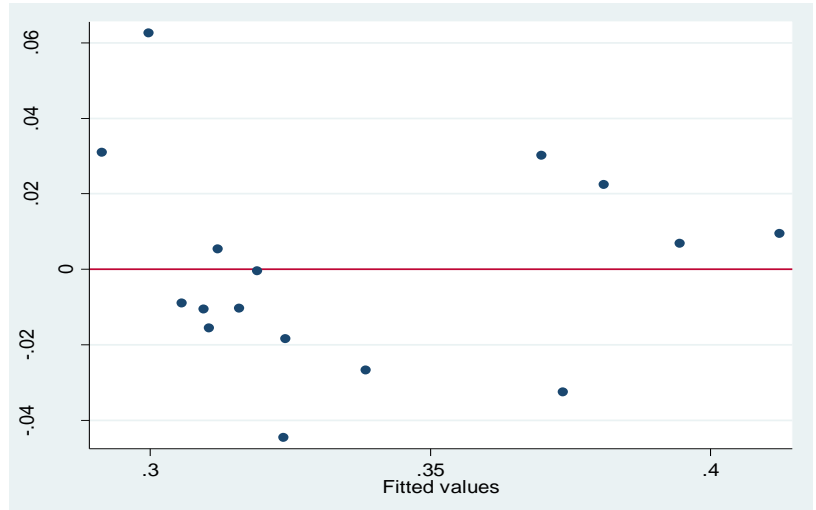

Model 6


Model 8

Model 9

\section{$(\mathrm{cc})$ EY}

This work is licensed under a Creative Commons Attribution 3.0 License. 